Universidade de São Paulo

Instituto de Biociências

Adrian David González Chaves

COBERTURA FLORESTAL VS. ISOLAMENTO: EFEITO DA PAISAGEM SOBRE A PROVISÃO DEMANDA E FLUXO DO SERVIÇO DE POLINIZAÇÃO

FOREST COVER vS. FOREST ISOLATION: THE LANDSCAPE EFFECT ON POLLINATION SERVICE SUPPLY, DEMAND AND FLOW TO COFFEE CROP

São Paulo

2016 
Adrian David González Chaves

COBERTURA FLORESTAL VS. ISOLAMENTO: EFEITO DA PAISAGEM SOBRE A PROVISÃO DEMANDA E FLUXO DO SERVIÇO DE POLINIZAÇÃO

FOREST COVER vS. FOREST ISOLATION: THE LANDSCAPE EFFECT ON POLLINATION SERVICE SUPPLY, DEMAND AND FLOW TO COFFEE CROP

Dissertação apresentada ao Instituto de Biociências da Universidade de São Paulo, para a obtenção de Título de Mestre em Ciências, na Área de Ecologia de Ecossistemas Terrestres e Aquáticos.

Orientadora: Dra. Astrid de Matos Peixoto Kleinert

Coorientador: Dr. Rodolfo Jaffé Ribbi

São Paulo 


\section{Ficha Catalográfica}

González Chaves, Adrian David

Cobertura florestal vs. isolamento: efeito da paisagem sobre a provisão demanda e fluxo do serviço de polinização

42 paginas

Dissertação (Mestrado) - Instituto de Biociências da Universidade de São Paulo. Departamento de Ecologia.

1. Mata Atlantica 2. Coffea arabica 3. Local landscape. Universidade de São Paulo. Instituto de Biociências.

Departamento de Ecologia.

\section{Comissão Julgadora:}

$\operatorname{Prof}(a)$. Dr(a).

Prof(a). Dr(a).

Prof(a). Dr.(a). 


\section{Epígrafe}

...It is when we act freely,

for the sake of the action itself

rather than for ulterior motives,

that we learn to become more

than what we were.

Mihaly Csikszentmihalyi 


\section{Agradecimentos}

Primeiramente agradeço a natureza da qual fazemos parte e inspira quere aprender dela. Agradeço pontualmente às abelhas que foram o foco central do trabalho, sem elas a gente não conseguiria nem disfrutar de muitas frutas com as quais começamos nossos dias. Na sequencia meus pais, quem tem me apoiado alongo da vida com muito amor e sabedoria indistintamente dos diversos caminhos que já escolhi até agora. Meu irmão que na distancia sempre tem sido uma fonte motivação e a minha sobrinha que com cinco anos já me explicou o que era a polinização. A Sofia amiga e companheira quem deu a forca e companhia para começar esta fase da vida no Brasil. Agradeço aos meus orientadores Astrid e Rodolfo e aos membros do comitê de acompanhamento, que foram pessoas chaves no desenvolvimento do projeto. A Cris que com a grande paciência e sabedoria que a caracterizam soube me acalmar e esclarecer em momentos cruciais no começo do projeto. Ao Jean Paul, quem tem sido uma pessoa super-receptiva que sempre abriu um espaço para tirar duvidas dar conselhos e apontar na direção certa, ajudando assim a melhorar consideravelmente o trabalho e crescer como pessoa.

Devo agradecer também a todos os fazendeiros que abriram as portas para a gente fazer os trabalhos de campo. Sempre com uma ótima atitude, que caracteriza ao povo mineiro. Dentro deles um agradecimento super especial para a família Leite: Marcus, Betty, Pedro, Paulo Enrique, Joao Marcus e a magnifica Tia Leny. Não só por facilitar o trabalho em campo de maneira significativa, mas também porque sempre me fizeram sentir em casa e como parte da maravilhosa família que eles são. Eternamente agradecido e afortunado por ter Ihes conhecido.

Ao pessoal dos laboratórios nos quais o trabalho foi desenvolvido. Ao laboratório de abelhas, local especial aonde cheguei pela primeira vez e tive a fortuna de compartilhar e conhecer pessoas como a Sheina, André, Liedson, William, Paula, Priscila e Guaraci. Pessoas maravilhosas com quem tive longas conversações, recebi um monte de dicas e conselhos fazendo assim do laboratório de uns dos melhores ambientes de trabalhos no qual já estive. Reforço o agradecimento para Sheina, William e Liedson quem me ajudaram em campo colaborando muito com seus conhecimentos resultado dos anos de experiência que eles todos tem trabalhando com abelhas. Agradecimento especial para Paulo Cesar quem foi um grande parceiro e amigo. Ao LEPaC, laboratório que teve a estrutura que permitiu que todo o trabalho de campo fosse desenvolvido. A Fernanda já que ajudando no mestrado dela foi o que me levo a Poços de Caldas, foi ela quem fez os primeiro contatos em campo e das discussões dos resultados delas que surgiriam as perguntam que estão sendo desenvolvidas neste trabalho. Ao Chico, Felipe, Juarez e especialmente a Larissa, Isabel e Karine, quem sempre com boa atitude e boa vontade forneceram um grande apoio em campo e no laboratório. À valentia da Natalia colega, amiga e coordenadora nata quem trabalhou em campo com muita garra, razão pela qual estarei infinitamente agradecido. Ao Leandro, quem com sua grande capacidade de ensinar, ajudou de transformar ideais em realidades por isso considero que sem ele o desenho amostral não fosse sido o que é.

Ao Instituto de Biociência e o Programa de Ecologia, quem tem pesquisadores incríveis que ajudaram enormemente na minha formação durante a minha passagem pela USP. Dentre deles quero agradecer a todos os participantes do curso de Campo com quem senti crescer como pessoa. Especial agradecimento à Gabi, Carol e Bruno (do grande Ergue!) quem com a boa atitude frente à 
vide, risadas e carinho que os caracteriza fizeram do tempo em campo um mês especial. À USP, lugar maravilhoso que me permitiu fazer novas amizades, dentre delas devo destacar aos parceiros de bebida, escalada e aventuras: o Arthur e o Eric. Ao grupo de escalada do Geobulder com quem comparti muitos momentos bons conseguindo assim oxigenar o cérebro em momentos de estresse. Finamente e não por isso menos importante agradeço e lhe dedico esta tese para minha avó, Tita. Mulher maravilhosa quem sempre tem me inspirado e motivado para continuar no mundo acadêmico, quem com sua postura ante a vida me ensino que nós somos nossos principais travas na vida. 


\section{Index}

Forest cover vs. Forest isolation: the landscape effect on pollination service provision coffee crop

02

Resumo

08

Abstract

09

Introduction

10

Materials and Methods

Study area

Coffee Bee Visitors

Coffee Pollination Service

Statistical analysis

Results

Discussion

References 


\title{
COBERTURA FLORESTAL VS. ISOLAMENTO: EFEITO DA PAISAGEM SOBRE A PROVISÃO DO SERVIÇO DE POLINIZAÇÃO
}

\author{
Adrian González-Chaves ${ }^{1 *}$, Rodolfo Jaffé ${ }^{1}$, Jean Paul Metzger ${ }^{1}$ and Astrid de M. P. Kleinert ${ }^{1}$ \\ ${ }^{1}$ Departamento de Ecologia, Universidade de São Paulo, Rua do Matão 321, 05508-090 São Paulo, \\ São Paulo, Brazil
}

RESUMO

Na medida em que as demandas agrícolas continuam se expandido, aumenta a necessidade de que a produção agrícola garanta a conservação da diversidade e a provisão de serviços ecossistêmicos. 0 intuito do trabalho é avaliar independentemente o efeito da distancia aos fragmentos florestais e a cobertura florestal numa escala local. Quantificamos a diversidade de abelhas e a formação de frutos em 24 cultivos de café dentro de paisagens complexas de $2 \mathrm{~km}$ de radio, compostas por mosaico de usos da terra, café, Mata Atlântica $(20-27 \%)$ e outros usos. Adicionalmente estimamos a contribuição das espécies na formação de frutos depois de uma visita única, em cinco dos 24 pontos amostrais. No total foram identificadas 31 espécies de abelhas visitando o café, a maioria abelhas sem ferrão (Meliponini) e abelhas da família Halictidae. Não houve diferença na formação de frutos depois das visitas únicas pelas diversas espécies de abelhas, o que sugere que há uma complementaridade na provisão do serviço. No entanto, a maior produtividade esteve associada à abundância de abelhas nativas. Em geral, houve um incremento de $8 \%$ com a presença das abelhas, que diminuiu com o aumento da distância aos fragmentos de mata e com o aumento da quantidade de café em escala local ( $400 \mathrm{~m}$ de raio no entorno do ponto amostral). $O$ efeito negativo da distância aos fragmentos reforça a importância da vegetação natural em prover diversidade de abelhas e por tanto o serviço de polinização. O efeito negativo da cobertura de café sobre a frutificação sugere que há um excesso de demanda que excede a capacidade dos polinizadores de prover o serviço dentro de paisagens complexas. Nossos resultados mostram que a estrutura da paisagem afeta a densidade, a riqueza e a composição de espécies de polinizadores. Por tanto, recomendamos, como estratégia para incrementar a produção de café, sem necessidade de aumentar a cobertura florestal, o manejo das áreas agrícolas para aumentar a dispersão entre fragmentos florestais e plantios de café, com o intuito de criar paisagens mais fragmentadas que facilitem o fluxo de polinizadores ao café.

Palavras chaves: Agro ecossistema, mudanças nos usos da terra, e Coffea arabica L. 


\title{
FOREST COVER VS. FOREST ISOLATION: THE LANDSCAPE EFFECT ON POLLINATION SERVICE SUPPLY TO COFFEE CROP
}

\author{
Adrian González-Chaves ${ }^{1 *}$, Rodolfo Jaffé ${ }^{1}$, Jean Paul Metzger ${ }^{1}$ and Astrid de M. P. Kleinert ${ }^{1}$ \\ ${ }^{1}$ Departamento de Ecologia, Universidade de São Paulo, Rua do Matão 321, 05508-090 São Paulo, \\ São Paulo, Brazil
}

\section{ABSTRACT}

As the demands on agricultural lands continue to expand, effective strategies are urgently needed to manage agricultural production to guarantee biodiversity conservation and ecosystem service provision. Here we assessed independently the effect of forest isolation and local forest cover over bee diversity and on the provision of pollination service to coffee. We quantified bee diversity of flower visitors and fruit set in 24 coffee fields within three complex landscape of $2 \mathrm{~km}$ radius surrounded by mosaic of coffee plantations, Atlantic forest fragments $(20-27 \%)$, pastures and other lands uses. Additionally, we estimated species contribution to fruit set after single visit in five of the 24 coffee sites. In total we identified 31 bee species visiting coffee flowers, most being stingless bees (Meliponini tribe) and sweat bees (Halictidae). The absence of difference in fruit set after single visit by Apis and natives bee suggest that service complementation. Although, higher abundances of sweat bees and stingless bees were positively related to fruit set. Coffee fruit set was overall $8 \%$ higher in the presence of bees, and responded negatively to isolation from forest fragments and to high coffee cover at a local landscape scale $(400 \mathrm{~m}$ radius landscape surrounding each sampled coffee bush). The negative association between isolation and fruit set reinforces the importance of natural vegetation to enhance bee diversity and therefore the provision of pollination service. The negative effect of coffee cover on fruit set suggests that the service demand can surpass pollinators' capacity to provide service within complex landscape. Our results provide clear evidences that landscape structure can affect the abundance, richness and composition of pollinators' species, and thus can indirectly regulate the provision of pollination service. Therefore we recommend, as a strategy to increase coffee yields without necessarily expanding forest cover, to manage agricultural landscapes in order to increase interspersion between forest fragments and coffee plantation thus a more patchy landscape mosaic that may facilitate pollinators flows to coffee crop.

KEY WORDS: Agro-ecosystems, land-use change and Coffea arabica L. 


\section{INTRODUCTION}

Animal pollination is extremely important to ensure the reproduction of more than $90 \%$ of all flowering plant species (Ollerton, Winfree \& Tarrant 2011), contributing hence to the maintenance of plant diversity in natural ecosystems (Buchmann \& Nabhan 1996; Kearns, Inouye \& Waser 1998). Pollination services also contributes to food production, as $70 \%$ of the commercial crops have an increase in harvest size and/or quality in the presence of pollinators (Heard 1999; Klein et al. 2007; Aizen et al. 2009). As demands on agricultural landscapes increases, improving crop yields through the enhancement of pollinators density and richness (ecological intensification) represents an alternative to meet such demands (Foley et al. 2011). It was recently reported that the enhancement of pollinators could help achieve higher yields for pollinated dependent crops worldwide (Garibaldi et al. 2016).

Most flowering plants are pollinated by multiple insect species, thus plants reproduction relies on the pollinators abundance (Waser et al. 1996; Vázquez, Morris \& Jordano 2005; Garibaldi et al. 2014). Managed bee species like Apis mellifera have been used to increase pollination service but they may not be able to account for all pollination demands as pollinator-dependent crops are increasing faster than honeybee populations (Aizen \& Harder 2009). Moreover, higher pollinator diversity may increase temporal and spatial stability in visitation rate (Klein 2009; Garibaldi et al. 2011a). Hence, attention on wild pollinators has increased as they naturally occur in agricultural landscapes, by relying on adjacent natural/semi-natural vegetation for nest and food resources (Losey \& Vaughn 2006; Brosi et al. 2008; Tscharntke et al. 2012). Wild bees have proven to be successful pollinators of exotic plants (Garibaldi et al. 2013) either directly or indirectly by enhancing managed pollinator efficiency (Garibaldi et al. 2014). Diverse bee assemblages are known to promote changes in foraging behaviour or spatially complement service provision over the crop plants (Brittain et al. 2013; Brittain, Kremen \& Klein 2013). Despite their importance both wild and managed pollinators are threatened by agricultural intensification (Bommarco et al. 2010).

Changes in the land use and land cover composition, mainly due to urbanization and agricultural intensification, have transformed natural habitats causing pollinator declines (Brown \& Paxton 2009; Potts et al. 2010), threatening the provision of pollination services (Biesmeijer et al. 2006; Bommarco et al. 2010; Vanbergen 2013). Today croplands and pastures occupy $\sim 40 \%$ of the Earth ice-free land surface (Ramankutty et al. 2008; Foley et al. 2011). Given that forest fragments adjacent to the focal crop work as pollinators' reservoirs (Taki, Kevan \& Ascher 2007; Brosi et al. 2008; Taki et al. 2011), the habitat amount in the landscape is an important indicator in predicting biodiversity (Fahrig 2013), 
and consequently pollination service (Garibaldi et al. 2013). This has been supported by recent metaanalysis which found that the main factor enhancing bee diversity was the amount of high-quality habitat, whereas the spatial arrangements of the type of land use or configuration of the land cover habitats on bee diversity was not important (Kennedy et al. 2013). However, in the aforementioned study the configuration was assessed through natural patches only, disregarding the spatial arrangement of the focal crop. Moreover, it was reported that bee diversity reliance on the amount of natural vegetation surrounding crop fields increases as fields become more homogeneous (large monocultures) (Batáry et al. 2011; Kennedy et al. 2013). For this reason, management practices to enhance bee diversity, like flower strips and/or hedgerows, are recommended for landscapes that have been severely altered (less that $20 \%$ of natural vegetation) (Batáry et al. 2011; Carvalheiro et al. 2011).

In contrast to studies that evaluate the effects of landscape on bee diversity, studies that have quantified the loss of pollination service, have measure it in relationship to isolation from natural patches (Ricketts et al. 2008; Garibaldi et al. 2011b), but have not differentiated between landscape configuration (e.g. isolation) and the surrounding landscape composition. However it is important to consider configuration and composition separately because under intermediate values of natural habitat there is the greatest variation of landscape configuration (Villard \& Metzger 2014) and there is also a steep loss of biodiversity (Banks-Leite et al. 2014). Thus the needs to disentangle which landscape attributes are causing biodiversity and pollination service loss. Even more importantly is to understand how already transformed landscapes can be managed to enhance pollination service provision (Vandermeer \& Perfecto 2007). Each landscape attributes can be associated to the elements on which service provision depends: supply, flow and demand (Mitchell et al. 2015), which in the case of pollination service associated as follows. Service supply would be the pool of pollinators in the landscapes, which could be represented by the habitat amount; Service flow which could be attributed to pollinators foraging behaviour over the crop land, thus restriction in the flow due to forest isolation could be interpreted as restriction in pollinators flow to crop. Whereas, the amount of crop cover in the landscape would represent the amount of crop that needs to be pollinated (service demand) (Mitchell et al. 2015). Thus understanding the relative effect of landscape attribute on ecosystem service provision could be better target management strategies.

Coffee is the second most important commodity in legal international trade ( $\mathrm{O}^{\prime}$ Brien \& Kinnaird 2003) and Brazil is the main coffee producer, responsible for more than $30 \%$ of the world exportation (International coffee organization - ICO 2015). Coffee production in Brazil replaced the Atlantic forest of which less than $16 \%$ remains today, most in small fragments found on private properties 
(Ribeiro et al. 2009). Although Coffea arabica L. has self-fertile flowers (auto-pollinated) (Ngo, Mojica \& Packer 2011), it exhibits increased levels of fruit set and yields in the presence of insect pollinators (Klein, Steffan-Dewenter \& Tscharntke 2003a; De Marco \& Coelho 2004; Ricketts 2004a; Klein 2009). Bees have been proposed as the main pollinators of coffee (Klein, Steffan-Dewenter \& Tscharntke 2003a; Munyuli 2011). Although past studies have measured the effect of forest isolation and farm management on coffee pollination (Klein, Steffan-Dewenter \& Tscharntke 2003a; De Marco \& Coelho 2004; Ricketts 2004a; Krishnan et al. 2012), no study has ever combined crop isolation and local (surrounding) composition to test how the landscape enhance bee diversity and pollination service provision.

The main objective of this study is thus to understand how landscape structure, particularly forest cover, isolation and matrix composition, affect bee diversity and coffee production. We suppose that the presence of forest patches within agricultural landscapes, by supporting bee populations, will increase coffee yields through enhancement of pollination service. Within complex landscape, composed by a mosaic of different land use and land cover classes, with $20 \%$ to $50 \%$ of natural areas, overall isolation from natural habitat might be reduced (Saturni et al., in prep). Thus we expect (1) that bee diversity will only be affected by isolation when there is low local forest cover surrounding crop sites. Coffee is expected to be pollinated by a variety of bee species; therefore we expect (2) that different species complement themselves in the service provision. Furthermore, bee movement between crop plants maximizes cross pollination, thus we expect higher chances of fructification after a single visit made by bees coming from a different bush than coming from the same bush (geitonogamy). If the former hypotheses are corroborated, we expect (3) coffee pollination to decay as bee diversity decreases. Furthermore, considering coffee cover in the local landscapes as a proxy of pollination demand, we expect shortages of pollinators supply and flow at sites with high coffee covers when isolated from forest fragments and/or with low local habitat amount.

By identifying key coffee pollinators, quantifying their relative contribution to pollination, and assessing how they are affected by landscape transformation, we hope to better understand how landscape contributes to stabilize and improve coffee production. By quantifying the independent effect of forest isolation and forest cover on mediating shifts in bee community composition and pollination service, we intend to fill knowledge gaps associated to relative effects of forest cover and configuration on pollination services (Fig. 1). 


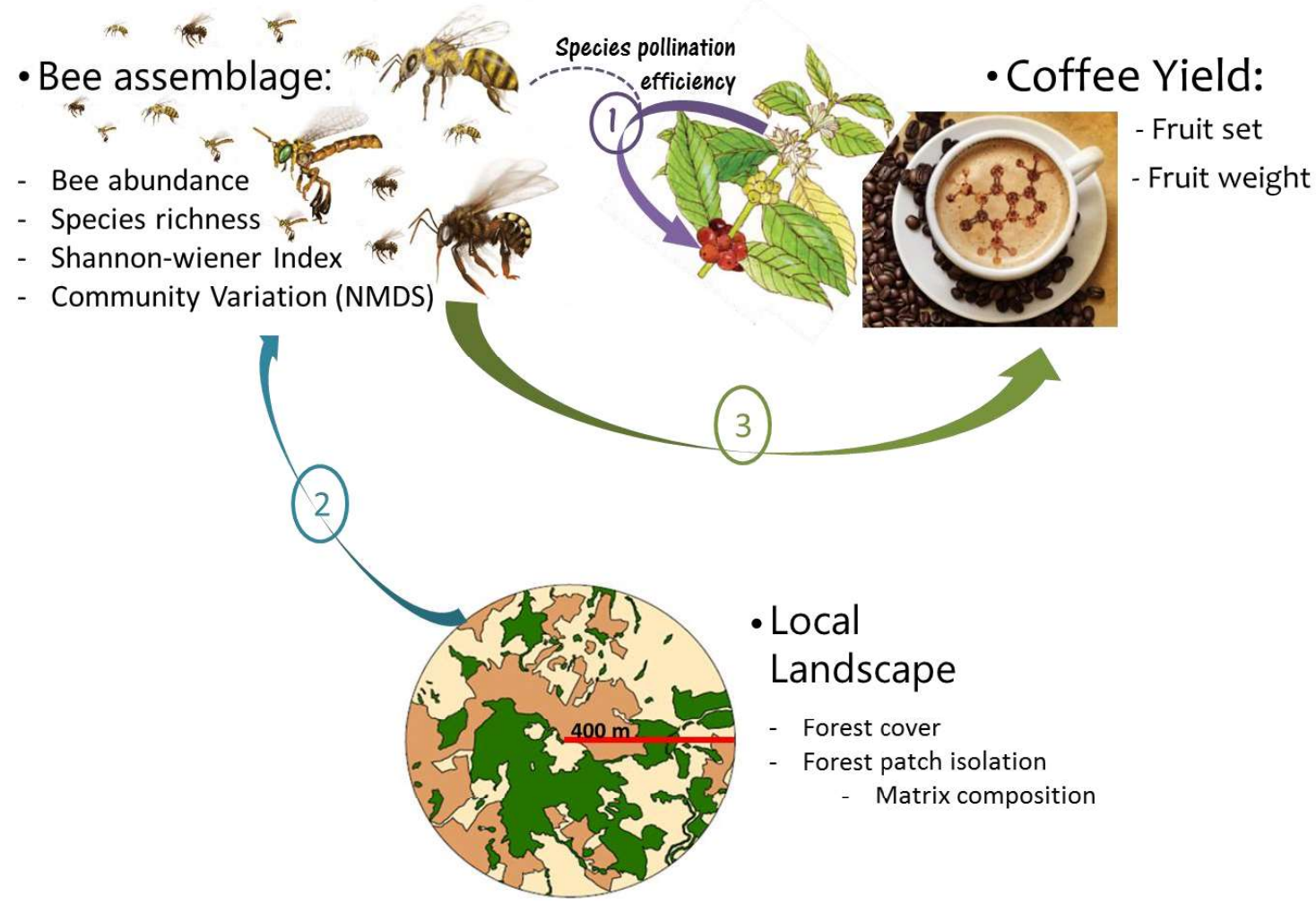

Fig. 1. Conceptual diagram presenting the main relationship (bullet points) explored in this study, the levels of analysis of the research (bullet points), each with the list of variables measured. We intended to evaluate the role of different species on coffee production using single visit experiments (1). In order to do so, landscape data of the focal crop was used to compare the relative effects of forest isolation and local forest cover on affects bee diversity (2). With the intention of testing how changes in bee assemblages affect coffee production (3).

\section{MATERIALS AND METHODS}

\section{Study Area}

The study region comprised the south east of Minas Gerais State, Brazil, one of the main coffee producing regions in the country. Sun coffee plantations are scattered between Atlantic Forest fragments along with pastures, sugar cane plantations and Eucalyptus forests. Our study areas comprised three circular landscapes of two-kilometre radius with coffee crops and similar forest cover, ranging from 20 to $27 \%$ (Fig. 2), a cover range where typically spatial configuration should be more variable (Villard \& Metzger 2014) . The amount of forest cover was determined based on highresolution images (ArcGis 10.3 basemap imagery from DigitalGlobe satellites for 2009 to $2011,0.5 \mathrm{~m}$ resolution) and a reference scale 1:5,000 (Fig. 3). In each landscape, we selected eight "local landscapes" (samples of landscape with $400 \mathrm{~m}$ radius) to evaluate the independent effects of local 
Table 5. Model selection statistics for fruit set and fruit weight using as predictor variables both landscape and bee diversity.

\begin{tabular}{llllll}
\hline Response & Models & Random & AIC & DAIC & weight \\
\hline \multirow{2}{*}{ Fruit Set } & $\begin{array}{l}\text { Treatment*Pan traps bee abundance, } \\
\text { Treatment*Community variation }\end{array}$ & $\begin{array}{l}\text { Landscape, } \\
\text { site, bush } \\
\text { and coffee } \\
\text { variety }\end{array}$ & 7239.7 & 0.0 & 0.782 \\
\hline \multirow{2}{*}{ Fruit weight } & null & Landscape, \\
& & site, bush & -741.9 & 0.00 & 0.981 \\
\hline
\end{tabular}

Table 6. Summary statistics for the selected models $(\Delta \mathrm{Alc}<2)$ for fruit set.

\begin{tabular}{llccc}
\hline Response & Predictor & Estimate & SE & $p$-value \\
\hline Fruit Set & Treatment (open): Pan traps bee abundance & 0.149 & 0.035 & $<0.001$ \\
\multirow{2}{*}{ Fruit Set } & Treatment (open): Community Variation & 0.218 & 0.051 & $<0.001$ \\
\hline
\end{tabular}

\section{DISCUSSION}

Natural vegetation patches within complex landscapes are known to enhance biodiversity (Tscharntke et al. 2005; Batáry et al. 2011). However our results show that not all the crop land within such landscapes is equally visit by bees. Coffee sites far away from forest fragments and/or highly surrounded by coffee presented lower bee richness and abundance. The reduction of bee richness and abundances due to isolation and/or to high coffee cover resulted in lower coffee fruit set, as high bee abundances were associated to higher coffee yields. Moreover, no differences were found in coffee fruit set after single visits made by wild bees or by Apis mellifera. Together these results support that there is a complementation among species in the service provision. However, not all bee species equally contributed to coffee fruit set, as changes in the community composition negatively affect coffee fruit set, in particular high abundances of bees of the genus Trigona. Overall coffee sites nearby forest fragments and/or with low coffee cover had high bee richness and abundances and the highest fruit set. Thus local landscape is mediating the pollination services through changes in bee assemblages. Therefore we suggest that the spatial management of the focal crop could enhance bee diversity within cropland, if the interspersion of cropland within forest patches is maximized. This would maintain a high pollination flow over the cropland, by reducing overall the crop-forest isolation. The local reduction of large coffee extensions would help to guarantee that the pool of pollinators' accounts for the service demand (Fig.8). 


\section{Bee assemblage and pollination service}

The exclusion experiments showed an overall increase of $8 \%$ in fruit set between coffee flowers left open in comparison to the flowers where pollinators were excluded. The increment in coffee fruit set increased up to $12 \%$ along with Halictidae bees' abundance (Fig. 7a, S2), although this result seems contradictory as sweat bees (Halictidae) were not found in abundance during the single visit experiment (Table S2). The Halictidae family has been reported to be the most abundant bee group in coffee systems and methodologies like the ones used in this study fail to truly record their abundances (Ngo et al. 2013). Moreover, highest coffee fruit set was found at small coffee patches adjacent to forest fragments, where the highest richness and abundance of sweet bees coincided with the highest stingless bees' richness and abundances. Thus these results suggest that both wild bee groups contribute to pollination service.

Even though there is no direct relationship between stingless bees and coffee fruit set, the higher yields found where stingless bee richness and abundance was highest reinforcing that wild bee contribute with pollination service to coffee (Veddeler et al. 2008). However not all stingless bees seem to contribute to fruit set, as increments of Trigona genus abundance resulted in reduced fruit set. This pattern could be attributed to the damage of flowers buds, that those species may cause, behaviour that has also been reported for other crops (see Saunders et al. 2015). Apis mellifera was the single most abundant specie found and even though their contribution to coffee yields is widely acknowledged (Roubik 2000, 2002; Ngo, Mojica \& Packer 2011), Apis mellifera abundance did not explain coffee fruit set variations. This result reinforces that relying on a single species attempts against agroecosystem resilience (Peterson, Allen \& Holling 1997; Kremen et al. 2007; Winfree et al. 2007; Garibaldi et al. 2013, 2015; Wilfert et al. 2016). Furthermore higher wild bees density and richness have been reported increase honey bee movements between crop plants (Brittain et al. 2013), thereby improving the chances of effective cross pollination ( $\mathrm{Ne}^{\prime} \mathrm{Eman}$ et al. 2010; King, Ballantyne \& Willmer 2013).

The single visit experiment suggests a complementation among the bees' species in the crop pollination service provision, as no difference was found in fruit set after a single visit made by a wild or a honey bee. Moreover, the lower coffee fruit set found after singles visit in comparison with the exclusion experiment could be attributed to the lack of effective visits, thus reinforcing the key role that bee abundance plays in increasing fruit set (Connelly, Poveda \& Loeb 2015). Single visits experiments showed that coffee fruit set was lower when bees visited flowers from the same coffee bush, before visiting the sampled flower, reinforcing that cross pollination by bees causes a 
significant increase in fruit set (Klein, Steffan-Dewenter \& Tscharntke 2003b). We would therefore expect higher bee richness and abundance to result in higher cross pollination (Brittain et al. 2013; Garibaldi et al. 2016).

\section{Forest cover vs. forest isolation}

Stingless bees were more abundant near forest fragments, but contrary to our expectations bees were not affected by local forest cover. Thus suggesting that proximity to forest fragment, independently of the amount of forest at the local scale, equally contribute to support rich bee assemblages (Table S6) and to the provision of pollination service (Taki, Kevan \& Ascher 2007; Taki et al. 2011), at least when the landscape forest cover is around $20-27 \%$. As at sites near forest fragments where fruit set was highest, stingless bees were more abundant and showed greater diversification in nesting sites (tree trunk cavities, exposed nest and ground nesters), size (1-2.8 mm) and foraging behaviour (Ramalho 2004; Brosi et al. 2008). It is noteworthy mentioning that lower bee abundances at far sites were associated to the absence of small bees and cavities nesting bees (See Supporting Information). Therefore our results reinforce that pollinators' flow is essentially restricted to crop land adjacent to forest fragments (Ricketts 2004b), especially to distances below $175 \mathrm{~m}$ in our complex landscapes.

The diverse nesting behaviour of stingless bees found visiting coffee seems to be associated with different response patterns to landscape transformations (Fig. 2). Out of the seven most abundant stingless bees, five were either exposed or ground nesters which have been seen to nest within the coffee crop (personal observation). The other two most abundant bees were tree cavity nesters (Fig. 5), which have been reported to benefit from anthropogenic landscapes (Batista, Ramalho \& Soares 2003). The low abundance of restricted tree nesters (Fig. 5) might be due to a lack of nesting resources as a result of the landscapes being below the biodiversity loss threshold (Table 1) (BanksLeite et al. 2014). After all the bee assemblages found are dominated by species more tolerant to landscape transformations (Batista, Ramalho \& Soares 2003; Jaffé et al. 2015) which could alternative explanation why local forest cover did not affect bee diversity. Nonetheless, the nonrestricted tree nesters response to isolation (see Supporting Information) reinforces that forest fragments provide resources for ground and exposed bee nesters as well (Brosi et al. 2008).

The community composition axis strongly associated to Trigona genus abundance (Fig. S5) which explained coffee fruit set (Fig $6 \mathrm{~b}$ ) did not respond to any of the landscape variables measured. This lack of association with forest isolation and/or local landscape composition could be attributed to $T$. spinipes exposed nesting behaviour, as they have been reported not to be fully reliant on forest (Jaffé 
et al. 2015). Hence, T. spinipes could be the species involved in the different effects of native bee community on coffee fruit set at different landscape scales (Saturni et al., in prep.). Thus more studies are needed to understand how the stingless bees' community interacts at a landscape level and their association to pollination service.

\section{Coffee cover}

The negative relationship between coffee cover and pollination service could attributed to the dilution effect (Veddeler, Klein \& Tscharntke 2006; Jha \& Vandermeer 2009), where the amount of bees cannot account for the amount of flowers to be visited (demand). Given that coffee cover, in our study, varies independently of forest cover and forest isolation, we therefore consider that an excess of service demand (crop extensification) is what is limiting service provision (Mitchell et al. 2015). This is consistent with a recent meta-analysis that found higher pollination benefits from increasing bee abundance at small crop fields (Garibaldi et al. 2016). The predominance of ground nesters in this complex landscapes also suggests that high local coffee cover is also negatively affecting the establishment of bees within cropland. After all landscape homogenization has been reported to negatively impact bee diversity and pollination service (Connelly, Poveda \& Loeb 2015) due to the lack of resources in the surroundings (Benton, Vickery \& Wilson 2003). Nonetheless, more studies are needed to understand how other types of cover affect bee diversity and pollination service to coffee.

\section{Implications and final remarks}

Our results for complex landscape suggest that: 1) Forest patch size did not affect the supply of bee diversity, within a regional context of intermediate forest cover (20-27\%). 2) increasing crop proximity to forest fragments would increment the accessibility and facilitate flow of pollinators to crops. 3) large extension of focal crop results in excessive service demands. We thus provide supporting evidence that fragmentation, within complex landscapes can have positive benefits on pollination service (Mitchell et al. 2015), and, as a consequence, that the provision of pollination services is heterogeneously distributed in space (Fig. 8). Once landscape structure affects pollination service, we suggest that if coffee cropland is to be expanded, then it should be done maintaining close distances to forest patches and avoiding large extensions of coffee. 

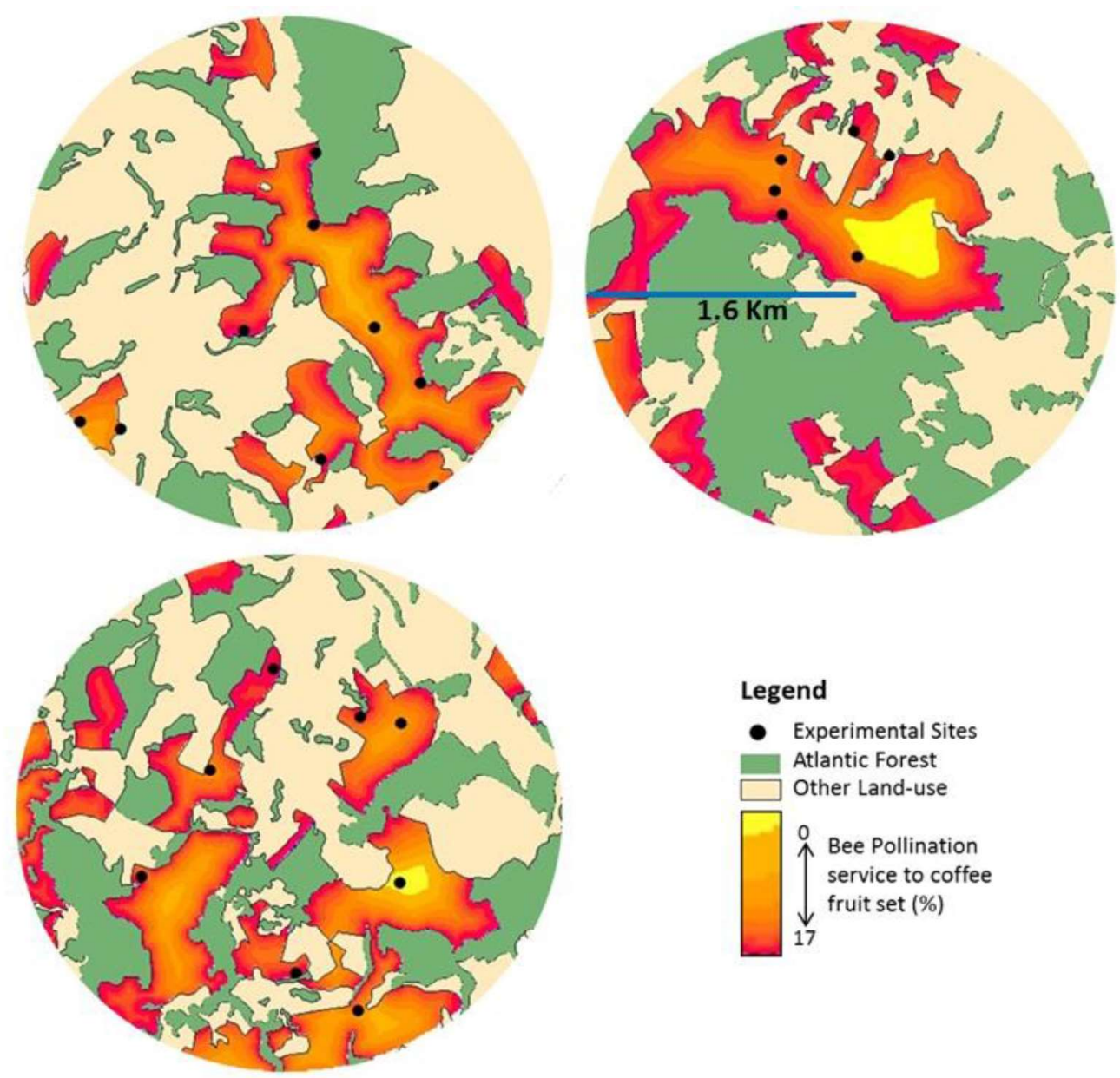

Fig. 8. Extrapolation of yield increments due to coffee bee pollination on the three 2-km landscapes using the best selected model considering distance to forest fragment and local coffee cover.

Our methodological approach using local landscape analysis can help to prioritized areas for management practices that enhance bee diversity, like flowers strip and hedgerows. After all, spatially managing cropland represents an alternative when is not possible (Perfecto \& Vandermeer 2010) or unacceptable by farmers (Burton, Kuczera \& Schwarz 2008) to increase forest cover. We therefore suggest efforts towards understanding how other land uses and landscape heterogeneity affect biodiversity and service provision, as heterogeneity could be achieved either by more diverse cover types or through a more complex spatial arrangement of cover types (Fahrig et al. 2011).

Finally our research have clear conservation implications, because most of the Atlantic forest remaining fragments are small and within private lands (Ribeiro et al. 2009), and we found strong evidence that reinforces the important role of any size forest fragments to supply wild pollinators. Therefore we support that landscape management to enhance pollination service could help to increase crop yields where pollination limitation occurs (Garibaldi et al. 2016). 


\section{REFRENCES}

Aizen, M.A., Garibaldi, L.A., Cunningham, S.A. \& Klein, A.M. (2009) How much does agriculture depend on pollinators? Lessons from long-term trends in crop production. Annals of Botany, 103, 1579-1588.

Aizen, M.A. \& Harder, L.D. (2009) The Global Stock of Domesticated Honey Bees Is Growing Slower Than Agricultural Demand for Pollination. Current Biology, 19, 915-918.

Araújo, E.D., Costa, M., Chaud-Netto, J. \& Fowler, H.G. (2004) Body size and flight distance in stingless bees (Hymenoptera: Meliponini): inference of flight range and possible ecological implications. Brazilian journal of biology = Revista brasleira de biologia, 64, 563-568.

Banks-Leite, C., Pardini, R., Tambosi, L.R., Pearse, W.D., Bueno, A. a, Bruscagin, R.T., Condez, T.H., Dixo, M., Igari, A.T., Martensen, A.C. \& Metzger, J.P. (2014) Using ecological thresholds to evaluate the costs and benefits of set-asides in a biodiversity hotspot. Science, 345, 1041-1045.

Barton, K. (2015) MuMIn: Multi-model inference. R package version 1.9.13. Version, 1, 18.

Batáry, P., Báldi, A., Kleijn, D. \& Tscharntke, T. (2011) Landscape-moderated biodiversity effects of agri-environmental management: a meta-analysis. Proceedings. Biological sciences / The Royal Society, 278, 1894-902.

Bates, D., Maechler, M., Bolker, B.M. \& Walker, S. (2014) Ime4: Linear mixed-effects models using Eigen and S4. Journal of Statistical Software, $\mathbf{x x}, \mathbf{x x}$.

Batista, M.A., Ramalho, M. \& Soares, A.E.E. (2003) Nesting sites and abundance of Meliponini (Hymenoptera: Apidae) in heterogeneous habitats of the Atlantic Rain Forest, Bahia, Brazil. Lundiana, 4, 19-23.

Benton, T.G., Vickery, J.A. \& Wilson, J.D. (2003) Farmland biodiversity: Is habitat heterogeneity the key? Trends in Ecology and Evolution, 18, 182-188.

Biesmeijer, J.C., Roberts, S.P.M., Reemer, M., Ohlemüller, R., Edwards, M., Peeters, T., Schaffers, A.P., Potts, S.G., Kleukers, R., Thomas, C.D., Settele, J. \& Kunin, W.E. (2006) Parallel declines in pollinators and insect-pollinated plants in Britain and the Netherlands. Science, 313, 351-354.

Bommarco, R., Biesmeijer, J.C., Meyer, B., Potts, S.G., Pöyry, J., Roberts, S.P.M., Steffan-Dewenter, I. \& Ockinger, E. (2010) Dispersal capacity and diet breadth modify the response of wild bees to habitat loss. Proceedings. Biological sciences / The Royal Society, 277, 2075-2082.

Brittain, C., Kremen, C. \& Klein, A.M. (2013) Biodiversity buffers pollination from changes in environmental conditions. Global Change Biology, 19, 540-547.

Brittain, C., Williams, N., Kremen, C. \& Klein, A. (2013) Synergistic effects of non-Apis bees and honey bees for pollination services. Proceedings. Biological sciences / The Royal Society, 280, 20122767.

Brosi, B.J., Daily, G.C., Shih, T.M., Oviedo, F. \& Durán, G. (2008) The effects of forest fragmentation on bee communities in tropical countryside. Journal of Applied Ecology, 45, 773-783.

Brown, M.J.F.F. \& Paxton, R.J. (2009) The conservation of bees : a global perspective. Apidologie, 40, 410-416.

Buchmann, S.L. \& Nabhan, G.P. (1996) The forgotten pollinators. The forgotten pollinators, 1, 312.

Burnham, K.P. \& Anderson, D.R. (2002) Model Selection and Multimodel Inference: A Practical Information-Theoretic Approach.

Burton, R.J.F., Kuczera, C. \& Schwarz, G. (2008) Exploring farmers' cultural resistance to voluntary agri-environmental schemes. Sociologia Ruralis, 48, 16-37.

Carvalheiro, L.G., Veldtman, R., Shenkute, A.G., Tesfay, G.B., Pirk, C.W.W., Donaldson, J.S. \& Nicolson, S.W. (2011) Natural and within-farmland biodiversity enhances crop productivity. Ecology Letters, 14, 251-259.

Connelly, H., Poveda, K. \& Loeb, G. (2015) Landscape simplification decreases wild bee pollination services to strawberry. Agriculture, Ecosystems \& Environment, 211, 51-56.

Fahrig, L. (2013) Rethinking patch size and isolation effects: The habitat amount hypothesis. Journal of Biogeography, 40, 1649-1663. 
Fahrig, L., Baudry, J., Brotons, L., Burel, F.G., Crist, T.O., Fuller, R.J., Sirami, C., Siriwardena, G.M. \& Martin, J.L. (2011) Functional landscape heterogeneity and animal biodiversity in agricultural landscapes. Ecology Letters, 14, 101-112.

Foley, J. a., Ramankutty, N., Brauman, K. a., Cassidy, E.S., Gerber, J.S., Johnston, M., Mueller, N.D., Connell, C.O., Ray, D.K., West, P.C., Balzer, C., Bennett, E.M., Sheehan, J., Siebert, S., Carpenter, S.R., Hill, J., Monfreda, C., Polasky, S., Rockstro, J., Tilman, D. \& Zaks, D.P.M. (2011) Solutions for a cultivated planet. Nature, 478, 337-342.

Garibaldi, L. a, Aizen, M. a, Klein, A.M., Cunningham, S. a \& Harder, L.D. (2011a) Global growth and stability of agricultural yield decrease with pollinator dependence. Proceedings of the National Academy of Sciences of the United States of America, 108, 5909-14.

Garibaldi, L.A., Bartomeus, I., Bommarco, R., Klein, A.M., Cunningham, S.A., Aizen, M.A., Boreux, V., Garratt, M.P.D., Carvalheiro, L.G., Kremen, C., Morales, C.L., Schüepp, C., Chacoff, N.P., Freitas, B.M., Gagic, V., Holzschuh, A., Klatt, B.K., Krewenka, K.M., Krishnan, S., Mayfield, M.M., Motzke, I., Otieno, M., Petersen, J., Potts, S.G., Ricketts, T.H., Rundlöf, M., Sciligo, A., Sinu, P.A., SteffanDewenter, I., Taki, H., Tscharntke, T., Vergara, C.H., Viana, B.F. \& Woyciechowski, M. (2015) Trait matching of flower visitors and crops predicts fruit set better than trait diversity. Journal of Applied Ecology, 52, 1436-1444.

Garibaldi, L.A., Carvalheiro, L.G., Leonhardt, S.D., Aizen, M.A., Blaauw, B.R., Isaacs, R., Kuhlmann, M., Kleijn, D., Klein, A.M., Kremen, C., Morandin, L., Scheper, J. \& Winfree, R. (2014) From research to action: Enhancing crop yield through wild pollinators. Frontiers in Ecology and the Environment, 12, 439-447.

Garibaldi, L.A., Carvalheiro, L.G., Vaissiere, B.E., Gemmill-Herren, B., Hipolito, J., Freitas, B.M., Ngo, H.T., Azzu, N., Saez, A., Astrom, J., An, J., Blochtein, B., Buchori, D., Garcia, F.J.C., Oliveira da Silva, F., Devkota, K., Ribeiro, M. d. F., Freitas, L., Gaglianone, M.C., Goss, M., Irshad, M., Kasina, M., Filho, A.J.S.P., Kiill, L.H.P., Kwapong, P., Parra, G.N., Pires, C., Pires, V., Rawal, R.S., Rizali, A., Saraiva, A.M., Veldtman, R., Viana, B.F., Witter, S. \& Zhang, H. (2016) Mutually beneficial pollinator diversity and crop yield outcomes in small and large farms. Science, 351, 388-391.

Garibaldi, L.A., Steffan-Dewenter, I., Kremen, C., Morales, J.M., Bommarco, R., Cunningham, S.A., Carvalheiro, L.G., Chacoff, N.P., Dudenhöffer, J.H., Greenleaf, S.S., Holzschuh, A., Isaacs, R., Krewenka, K., Mandelik, Y., Mayfield, M.M., Morandin, L.A., Potts, S.G., Ricketts, T.H., Szentgyörgyi, H., Viana, B.F., Westphal, C., Winfree, R. \& Klein, A.M. (2011b) Stability of pollination services decreases with isolation from natural areas despite honey bee visits. Ecology Letters, 14, 1062-1072.

Garibaldi, L. a, Steffan-Dewenter, I., Winfree, R., Aizen, M. a, Bommarco, R., Cunningham, S. a, Kremen, C., Carvalheiro, L.G., Harder, L.D., Afik, O., Bartomeus, I., Benjamin, F., Boreux, V., Cariveau, D., Chacoff, N.P., Dudenhöffer, J.H., Freitas, B.M., Ghazoul, J., Greenleaf, S., Hipólito, J., Holzschuh, A., Howlett, B., Isaacs, R., Javorek, S.K., Kennedy, C.M., Krewenka, K.M., Krishnan, S., Mandelik, Y., Mayfield, M.M., Motzke, I., Munyuli, T., Nault, B. a, Otieno, M., Petersen, J., Pisanty, G., Potts, S.G., Rader, R., Ricketts, T.H., Rundlöf, M., Seymour, C.L., Schüepp, C., Szentgyörgyi, H., Taki, H., Tscharntke, T., Vergara, C.H., Viana, B.F., Wanger, T.C., Westphal, C., Williams, N. \& Klein, A.M. (2013) Wild pollinators enhance fruit set of crops regardless of honey bee abundance. Science (New York, N.Y.), 339, 1608-11.

Greenleaf, S.S., Williams, N.M., Winfree, R. \& Kremen, C. (2007) Bee foraging ranges and their relationship to body size. Oecologia, 153, 589-596.

Heard, T.A. (1999) the Role of Stingless Bees in Crop Pollination. , 183-206.

Jaffé, R., Castilla, A., Pope, N., Imperatriz-Fonseca, V.L., Metzger, J.P., Arias, M.C. \& Jha, S. (2015) Landscape genetics of a tropical rescue pollinator. Conservation Genetics.

Jha, S. \& Vandermeer, J.H. (2009) Contrasting bee foraging in response to resource scale and local habitat management. Oikos, 118, 1174-1180.

Kearns, C.A., Inouye, D.W. \& Waser, N.M. (1998) ENDANGERED MUTUALISMS: The Conservation of 
Plant-Pollinator Interactions. Annual Review of Ecology and Systematics, 83-112.

Kennedy, C.M., Lonsdorf, E., Neel, M.C., Williams, N.M., Ricketts, T.H., Winfree, R., Bommarco, R., Brittain, C., Burley, A.L., Cariveau, D., Carvalheiro, L.G., Chacoff, N.P., Cunningham, S. a., Danforth, B.N., Dudenhöffer, J.H., Elle, E., Gaines, H.R., Garibaldi, L. a., Gratton, C., Holzschuh, A., Isaacs, R., Javorek, S.K., Jha, S., Klein, A.M., Krewenka, K., Mandelik, Y., Mayfield, M.M., Morandin, L., Neame, L. a., Otieno, M., Park, M., Potts, S.G., Rundlöf, M., Saez, A., SteffanDewenter, I., Taki, H., Viana, B.F., Westphal, C., Wilson, J.K., Greenleaf, S.S. \& Kremen, C. (2013) A global quantitative synthesis of local and landscape effects on wild bee pollinators in agroecosystems. Ecology Letters, 16, 584-599.

King, C., Ballantyne, G. \& Willmer, P.G. (2013) Why flower visitation is a poor proxy for pollination: Measuring single-visit pollen deposition, with implications for pollination networks and conservation. Methods in Ecology and Evolution, 4, 811-818.

Klein, A.M. (2009) Nearby rainforest promotes coffee pollination by increasing spatio-temporal stability in bee species richness. Forest Ecology and Management, 258, 1838-1845.

Klein, A.-M., Steffan-Dewenter, I. \& Tscharntke, T. (2003a) Fruit set of highland coffee increases with the diversity of pollinating bees. Proceedings of the Royal Society B: Biological Sciences, 270, 955-961.

Klein, A.M., Steffan-Dewenter, I. \& Tscharntke, T. (2003b) Bee pollination and fruit set of Coffea arabica and C. canephora (Rubiaceae). American Journal of Botany, 90, 153-157.

Klein, A.-M., Vaissiere, B.E., Cane, J.H., Steffan-Dewenter, I., Cunningham, S.A., Kremen, C. \& Tscharntke, T. (2007) Importance of pollinators in changing landscapes for world crops. Proceedings of the Royal Society B: Biological Sciences, 274, 303-313.

Kremen, C., Williams, N.M., Aizen, M.A., Gemmill-Herren, B., LeBuhn, G., Minckley, R., Packer, L., Potts, S.G., Roulston, T., Steffan-Dewenter, I., Vázquez, D.P., Winfree, R., Adams, L., Crone, E.E., Greenleaf, S.S., Keitt, T.H., Klein, A.M., Regetz, J. \& Ricketts, T.H. (2007) Pollination and other ecosystem services produced by mobile organisms: A conceptual framework for the effects of land-use change. Ecology Letters, 10, 299-314.

Krishnan, S., Kushalappa, C.G., Shaanker, R.U. \& Ghazoul, J. (2012) Status of pollinators and their efficiency in coffee fruit set in a fragmented landscape mosaic in South India. Basic and Applied Ecology, 13, 277-285.

Krug, C. \& Alves-dos-Santos, I. (2008) O Uso de Diferentes Métodos para Amostragem da Fauna de Abelhas (Hymenoptera: Apoidea), um Estudo em Floresta Ombrófila Mista em Santa Catarina. Neotropical Entomology, 37, 265-278.

Losey, J.E. \& Vaughn, M. (2006) The Economic Value of Ecological Services Provided by Insects. BioScience, 56, 311.

De Marco, P. \& Coelho, F.M. (2004) Services performed by the ecosystem: Forest remnants influence agricultural cultures' pollination and production. Biodiversity and Conservation, 13, 1245-1255.

Mitchell, M.G.E., Suarez-Castro, A.F., Martinez-Harms, M., Maron, M., McAlpine, C., Gaston, K.J., Johansen, K. \& Rhodes, J.R. (2015) Reframing landscape fragmentation's effects on ecosystem services. Trends in Ecology and Evolution, 30, 190-198.

Munyuli, T. (2011) Factors governing flower visitation patterns and quality of pollination services delivered by social and solitary bee species to coffee in central Uganda. African Journal of Ecology, 49, 501-509.

Ne'Eman, G., Jürgens, A., Newstrom-Lloyd, L., Potts, S.G. \& Dafni, A. (2010) A framework for comparing pollinator performance: Effectiveness and efficiency. Biological Reviews, 85, 435451.

Ngo, H.T., Gibbs, J., Griswold, T. \& Packer, L. (2013) Evaluating bee (Hymenoptera: Apoidea) diversity using Malaise traps in coffee landscapes of Costa Rica. Canadian Entomologist, 145, 435-453.

Ngo, H.T., Mojica, A.C. \& Packer, L. (2011) Coffee plant - pollinator interactions: a review. Canadian Journal of Zoology, 89, 647-660. 
O'Brien, T.G. \& Kinnaird M.F. (2003) CONSERVATION: Caffeine and Conservation. Science, 300, 587587.

Ollerton, J., Winfree, R. \& Tarrant, S. (2011) How many flowering plants are pollinated by animals? Oikos, 120, 321-326.

Perfecto, I. \& Vandermeer, J. (2010) The agroecological matrix as alternative to the landsparing/agriculture intensification model. Proceedings of the National Academy of Sciences of the United States of America, 107, 5786-5791.

Peterson, G., Allen, C.R. \& Holling, C.S. (1997) Ecological Resilience, Biodiversity, and Scale. Ecosystems, 1, 6-18.

Potts, S.G., Biesmeijer, J.C., Kremen, C., Neumann, P., Schweiger, O. \& Kunin, W.E. (2010) Global pollinator declines: Trends, impacts and drivers. Trends in Ecology and Evolution, 25, 345-353.

Quinn, G.P. \& Keough, M.J. (2002) Experimental Design and Data Analysis for Biologists.

Ramalho, M. (2004) Stingless bees and mass flowering trees in the canopy of Atlantic Forest: a tight relationship. Acta Botanica Brasilica, 18, 37-47.

Ramankutty, N., Evan, A.T., Monfreda, C. \& Foley, J.A. (2008) Farming the planet: 1. Geographic distribution of global agricultural lands in the year 2000. Global Biogeochemical Cycles, 22, 119.

Ribeiro, M.C., Metzger, J.P., Martensen, A.C., Ponzoni, F.J. \& Hirota, M.M. (2009) The Brazilian Atlantic Forest: How much is left, and how is the remaining forest distributed? Implications for conservation. Biological Conservation, 142, 1141-1153.

Ricketts, T.H. (2004a) Tropical Forest Fragments Enhance Pollinator Activity in Nearby Coffee Crops \rFragmentos de Bosque Tropical Incrementan la Actividad de Polinizadores en Cultivos de Café Cercanos. Conservation Biology, 18, 1262-1271.

Ricketts, T.H. (2004b) Tropical Forest Fragments Enhance Pollinator Activity in Nearby Coffee Crops\rFragmentos de Bosque Tropical Incrementan la Actividad de Polinizadores en Cultivos de Café Cercanos. Conservation Biology, 18, 1262-1271.

Ricketts, T., Daily, G., Ehrlich, P. \& Michener, C. (2004) Economic value of tropical forest to coffee production. Proceedings of the National Academy of Sciences of the United States of America, 101, 12579-12661.

Ricketts, T.H., Regetz, J., Steffan-Dewenter, I., Cunningham, S.A., Kremen, C., Bogdanski, A., GemmillHerren, B., Greenleaf, S.S., Klein, A.M., Mayfield, M.M., Morandin, L.A., Ochieng', A. \& Viana, B.F. (2008) Landscape effects on crop pollination services: Are there general patterns? Ecology Letters, 11, 499-515.

Roubik, D.W. (2000) Pollination system stability in tropical America. Conservation Biology, 14, 12351236.

Roubik, D.W. (2002) Feral African bees augment neotropical coffee yield. Pollinating bees: the conservationlink between agriculture and nature (eds P.G. Kevan), \& V.L. Imperatriz-Fonseca), pp. 255 - 266. Ministry of Environment, Brasília.

Saunders, M.E., Peisley, R.K., Rader, R. \& Luck, G.W. (2015) Pollinators, pests, and predators: Recognizing ecological trade-offs in agroecosystems. Ambio, 45, 4-14.

Taki, H., Kevan, P.G. \& Ascher, J.S. (2007) Landscape effects of forest loss in a pollination system. Landscape Ecology, 22, 1575-1587.

Taki, H., Yamaura, Y., Okabe, K. \& Maeto, K. (2011) Plantation vs. natural forest: Matrix quality determines pollinator abundance in crop fields. Scientific Reports, 1, 1-4.

Tscharntke, T., Klein, A.M., Kruess, A., Steffan-Dewenter, I. \& Thies, C. (2005) Landscape perspectives on agricultural intensification and biodiversity - Ecosystem service management. Ecology Letters, 8, 857-874.

Tscharntke, T., Tylianakis, J.M., Rand, T.A., Didham, R.K., Fahrig, L., Batáry, P., Bengtsson, J., Clough, Y., Crist, T.O., Dormann, C.F., Ewers, R.M., Fründ, J., Holt, R.D., Holzschuh, A., Klein, A.M., Kleijn, D., Kremen, C., Landis, D.A., Laurance, W., Lindenmayer, D., Scherber, C., Sodhi, N., Steffan- 
Dewenter, I., Thies, C., van der Putten, W.H. \& Westphal, C. (2012) Landscape moderation of biodiversity patterns and processes - eight hypotheses. Biological Reviews, 87, 661-685.

Vanbergen, A.J. (2013) Threats to an ecosystem service: Pressures on pollinators. Frontiers in Ecology and the Environment, 11, 251-259.

Vandermeer, J. \& Perfecto, I. (2007) The Agricultural Matrix and a Future Paradigm for Conservation. Conservation Biology, 21, 274-277.

Vázquez, D.P., Morris, W.F. \& Jordano, P. (2005) Interaction frequency as a surrogate for the total effect of animal mutualists on plants. Ecology Letters, 8, 1088-1094.

Veddeler, D., Klein, A.M. \& Tscharntke, T. (2006) Contrasting responses of bee communities to coffee flowering at different spatial scales. Oikos, 112, 594-601.

Veddeler, D., Olschewski, R., Tscharntke, T. \& Klein, A.M. (2008) The contribution of non-managed social bees to coffee production: New economic insights based on farm-scale yield data. Agroforestry Systems, 73, 109-114.

Villard, M.A. \& Metzger, J.P. (2014) Beyond the fragmentation debate: A conceptual model to predict when habitat configuration really matters. Journal of Applied Ecology, 51, 309-318.

Waser, N.M., Chittka, L., Price, M. V., Williams, N.M. \& Ollerton, J. (1996) Generalization in pollination systems, and why it matters. Ecology, 77, 1043-1060.

Wilfert, L., Long, G., Leggett, H.C., Schmid-Hempel, P., Butlin, R., Martin, S.J.M. \& Boots, M. (2016) Deformed wing virus is a recent global epidemic in honeybees driven by Varroa mites. Science, 351, 594-597.

Winfree, R., Williams, N.M., Dushoff, J. \& Kremen, C. (2007) Native bees provide insurance against ongoing honey bee losses. Ecology Letters, 10, 1105-1113. 


\section{Supporting Information}

\section{Bee trait classification}

The net sampled bees were classified according to their size using the intertegular distance (ITD) as a proxy for bee size (Cane 1986). Since the size of the intertegular distance of the sampled bees ranged between $1 \mathrm{~mm}$ to $3.6 \mathrm{~mm}$, and only five (5) of the 20 identified morphospecies exhibited an ITD above $2 \mathrm{~mm}$, we grouped bees as small (ITD $<1.64 \mathrm{~mm}$ ) and medium (ITD $>1.64 \mathrm{~mm}$ ). Based on the revision on the neotropical bees (Camargo et al. 2007), the species were also classified according the most common nesting type cited. Two categories were considered in the analysis: cavities nesting bees vs. non-cavities nesting bees.

This data was not included in the general analysis as there was a zero inflated problem for small and cavity and ground nesting bees, due to their absence in the far experimental sites. Nonetheless for the other classifications analysis were possible: Meliponini tribe, exposed nesting bees (Trigona spinipes, Trigona hyalinata and Apis mellifera), and medium sized bees.

\section{SUPPLEMENTARY FIGURES}

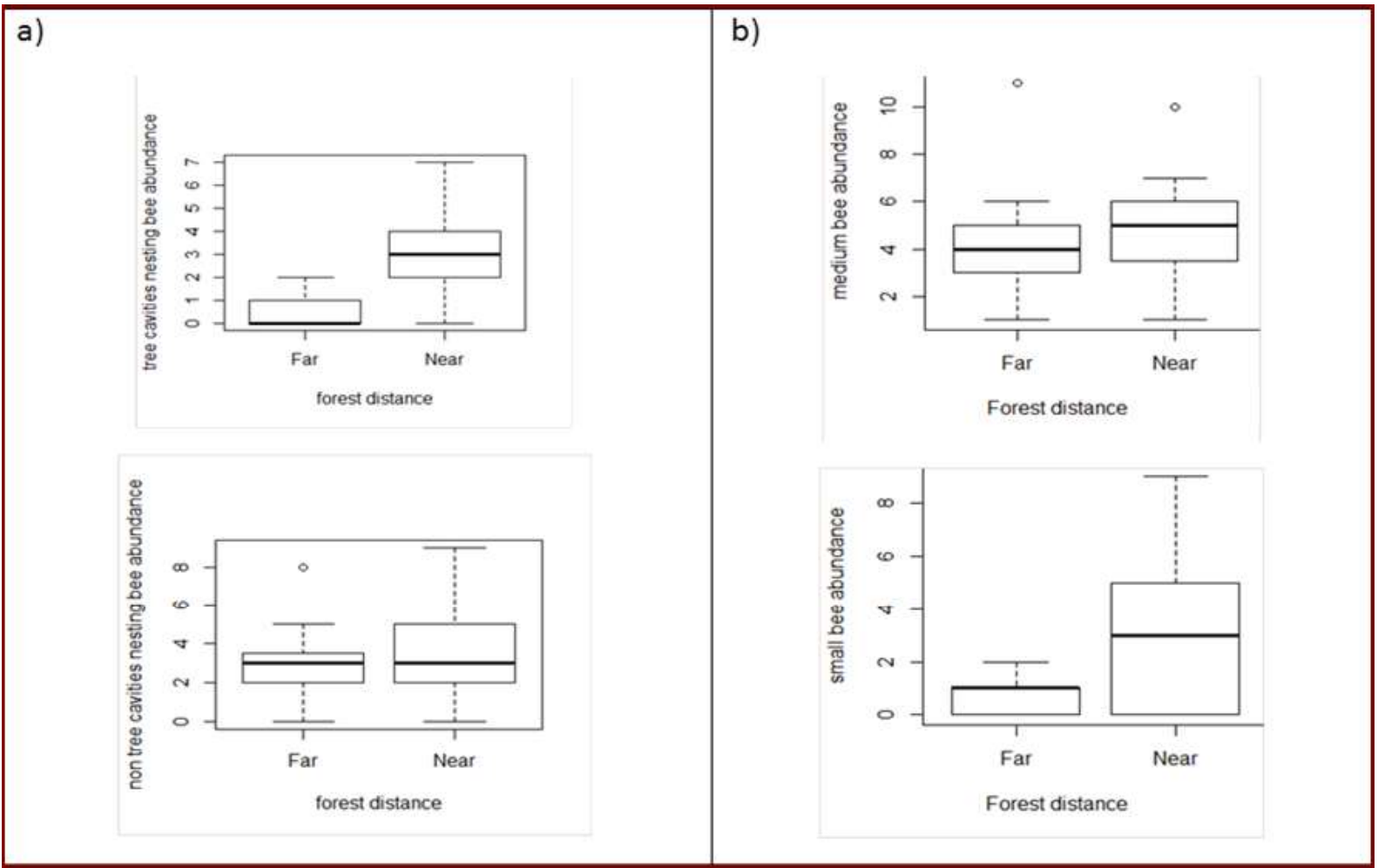

Fig. S1. Effect of distance over two functional categories: nesting behaviour (a) and bee size (b). 


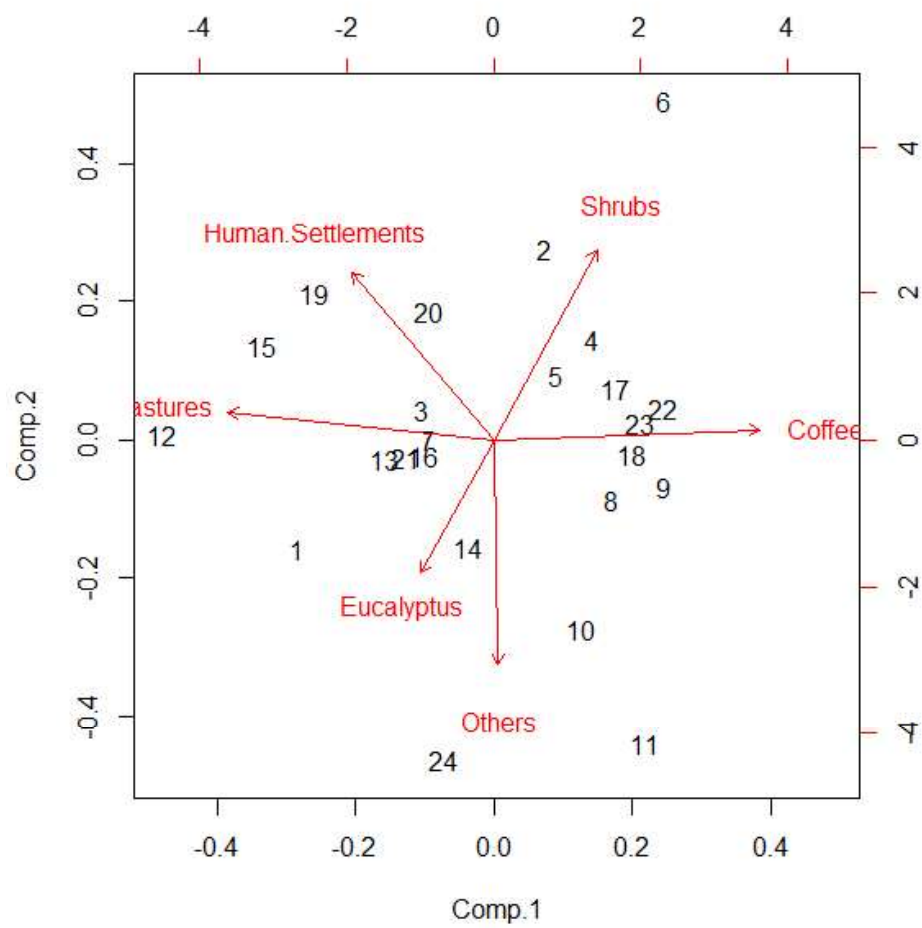

Fig. S2. Principal Component Analysis (PCA) using the percentage of landscape covers of each land use type (matrix composition) on the 24 local landscapes. The first axis explains $36 \%$ of the variance.

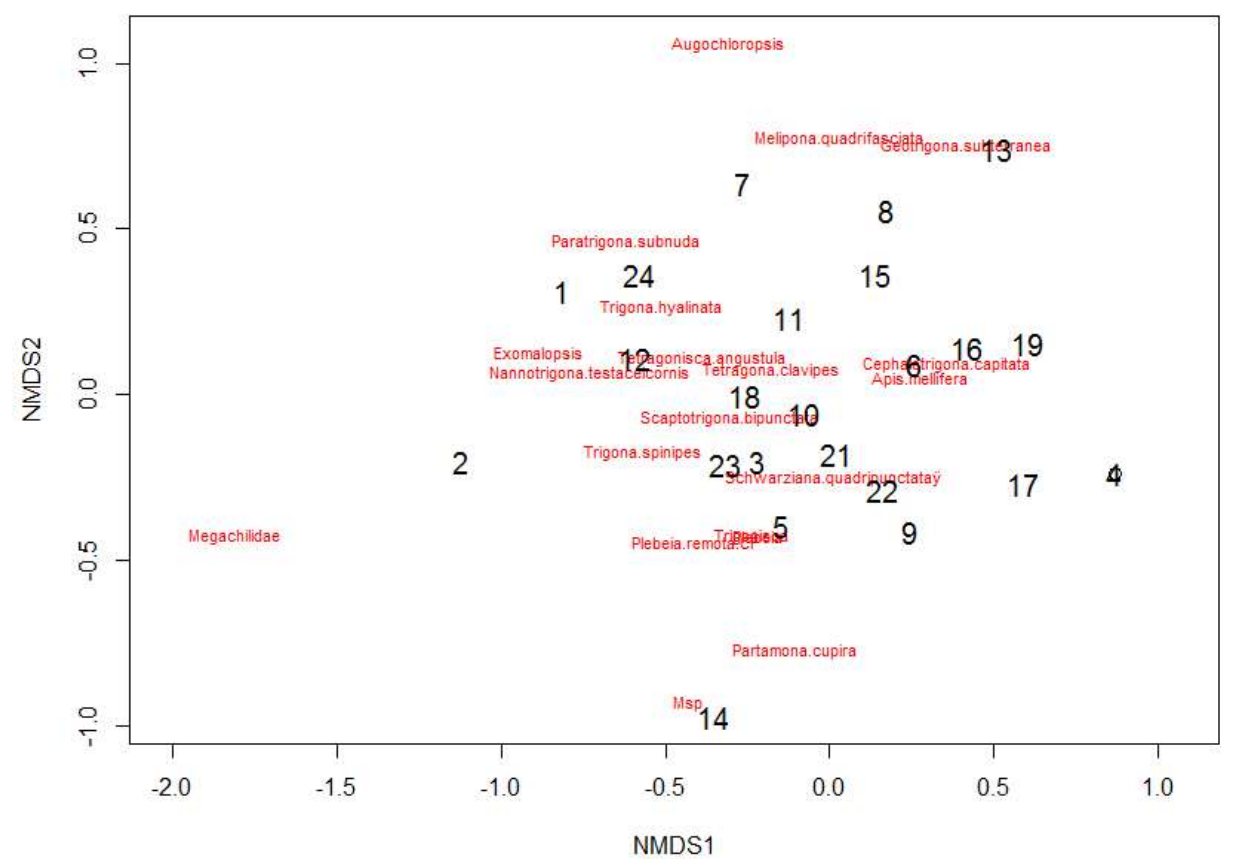

Fig. S3. Community variation analyses with Non-metric Dimensional Scaling (NMDS) using the abundance/presence of visiting species sampled with entomological nets in each of the 24 coffee sites. In red, species names and in black the experimental sites. 
Table S1. Response and predictor variables considered for the analyses.

\begin{tabular}{|l|l|}
\hline \multicolumn{1}{|c|}{ RESPONSE VARIABLES } & \multicolumn{1}{|c|}{ PREDICTOR VARIABLES } \\
\hline \multicolumn{2}{|c|}{ a) Effect of local landscape variables over bee diversity } \\
\hline $\begin{array}{l}\text { Bee abundance (nets and pan traps) } \\
\text { Bee richness (nets, pan traps and total) } \\
\text { Shannon Index (nets) } \\
\text { Community variation (NMDS) }\end{array}$ & $\begin{array}{l}\text { Distance to forest fragments } \\
\text { Percentage of forest cover (400m radius) } \\
\text { Percentage of coffee cover (400m radius) } \\
\text { Percentage of pasture cover (400m radius) } \\
\text { Matrix composition: from more pasture to more } \\
\text { coffee (PCA first axis). }\end{array}$ \\
\hline \multicolumn{2}{|l|}{ b) Effect of bee diversity over coffee production } \\
\hline $\begin{array}{l}\text { Fruit set } \\
\text { Fruit weight }\end{array}$ & $\begin{array}{l}\text { Bee abundance (nets and pan traps) } \\
\text { Bee richness (nets, pan traps and total) } \\
\text { Shannon Index (nets) } \\
\text { Community variation (NMDS) }\end{array}$ \\
\hline \multicolumn{2}{|c|}{ c) Single visit over coffee production } \\
\hline
\end{tabular}

Table S2. Number of single visits of a virgin coffee flower, performed by bee species observed in the study sites. Fruit set is the percentage of single visited flowers that ripped. (FC = Forest Cover).

\begin{tabular}{lccccccc}
\hline Species & Visits & $\begin{array}{c}\text { Same } \\
\text { Bush* }\end{array}$ & $\begin{array}{c}\text { Other } \\
\text { Bush* }\end{array}$ & Fruits & $\begin{array}{c}\text { Fruit } \\
\text { Set (\%) }\end{array}$ & $\begin{array}{c}\text { Near \& } \\
\text { High FC }\end{array}$ & $\begin{array}{c}\text { Far \& } \\
\text { Low FC }\end{array}$ \\
\hline Apis mellifera & 73 & 41 & 32 & 32 & 44 & 37 & 36 \\
Plebeia sp. & 31 & 4 & 27 & 10 & 32 & 31 & 0 \\
Schwarziana quadripunctata & 9 & - & - & 2 & 22 & 9 & 0 \\
Scaptotrigona & 8 & 1 & 7 & 3 & 38 & 8 & 0 \\
Meliponini sp. & 5 & - & - & 3 & 60 & 5 & 0 \\
Plebeia remota & 4 & 0 & 4 & 4 & 100 & 4 & 0 \\
Trigona sp & 4 & 1 & 3 & 0 & 0 & 3 & 1 \\
Melipona quadrifasciata & 3 & 2 & 1 & 1 & 33 & 3 & 0 \\
Jataí & 2 & 0 & 2 & 0 & 0 & 2 & 0 \\
Paratrigona subnuda & 2 & 0 & 2 & 1 & 50 & 2 & 0 \\
Halictidae sp. & 1 & 0 & 1 & 1 & 100 & 1 & 0 \\
\hline
\end{tabular}


Table S3. Results of GGLM model selection for the effect of local landscape variables over bee richness, the likelihood ratio test and LRT $p$-value for the variables of the best model selected using Akaike Corrected criterion.

\begin{tabular}{|c|c|c|c|c|}
\hline Response & Models & Random effect & LRT & $p$-value \\
\hline \multirow[t]{10}{*}{ Richness (nets) } & Distance (m) & Landscape & & \\
\hline & Distance & & 7.29 & $0.007^{* *}$ \\
\hline & Distance (categorical) & Landscape & & \\
\hline & Distance & & 6.53 & $0.011^{*}$ \\
\hline & Coffee_400, Distance & Landscape & & \\
\hline & Coffee_400 & & 0.01 & 0.93 \\
\hline & Distance & & 6.87 & $0.009 * *$ \\
\hline & Pastures_400, Distance & Landscape & & \\
\hline & Pastures_400 & & 0.01 & 0.94 \\
\hline & Distance & & 7.29 & $0.007^{* *}$ \\
\hline \multirow{4}{*}{$\begin{array}{l}\text { Richness } \\
\text { (Pantraps) }\end{array}$} & PCA1 - Matrix variation & Landscape & & \\
\hline & Matrix variation & & 16.77 & $>0.001 * * *$ \\
\hline & Coffee cover (400-m radius) & Landscape & & \\
\hline & Coffee cover & & 16.59 & $>0.001 * * *$ \\
\hline
\end{tabular}

Table S4. Results of GGLM model selection for the effect of local landscape variables over bee abundance, the likelihood ratio test and LRT $p$-value for the variables of the best model selected using Akaike Corrected criterion.

\begin{tabular}{|c|c|c|c|c|}
\hline Response & Models & Random effect & LRT & $p$-value \\
\hline \multirow[t]{3}{*}{ Abundance (nets) } & Coffee_400, Distance (m) & Landscape & & \\
\hline & Coffee_400 & & 5.87 & $0.015^{*}$ \\
\hline & Distance (m) & & 8.96 & $0.003 * *$ \\
\hline \multirow{5}{*}{$\begin{array}{l}\text { Abundance } \\
\text { (pantraps) }\end{array}$} & Coffee cover (400-m radius) & Landscape & & \\
\hline & Coffee cover & & 49.07 & $>0.001 * * *$ \\
\hline & Coffee_400, Distance & Landscape & & \\
\hline & Coffee cover & & 46.697 & $>0.001 * * *$ \\
\hline & Distance & & 0.27 & 0.602 \\
\hline \multirow{3}{*}{$\begin{array}{l}\text { Abundance } \\
\text { (Meliponini) }\end{array}$} & Coffee_400, Distance (m) & None & & \\
\hline & Coffee cover & & 4.86 & $0.023^{*}$ \\
\hline & Distance & & 6.64 & $0.010^{*}$ \\
\hline
\end{tabular}




\begin{tabular}{llll} 
Distance $(\mathrm{m})$ & None & & \\
Distance & & 7.97 & $0.005^{* *}$ \\
F2 - Matrix variation & None & & \\
Matrix variation & & 6.77 & $0.009^{* *}$ \\
\hline
\end{tabular}

Table S5. Correlation values, $p$-values and graphs of the species abundances, of the bees correlated, with the first axis of the Non-Dimensional Multi Scale (NMDS). The nesting site and nectar robber behaviour is also presented for each species. Trigona spinipes, Trigona hyalinata, Paratrigona subnuda, Nannotrigona testicornis, Tetragonisca angustula.

\begin{tabular}{clcccc}
\hline $\begin{array}{c}\text { Bee species } \\
\text { abundance }\end{array}$ & $\begin{array}{l}\text { Community } \\
\text { Composition } \\
\text { (First axis) }\end{array}$ & $\mathbf{R}^{2}$ & $p$-values & $\begin{array}{c}\text { Nesting } \\
\text { site }\end{array}$ & $\begin{array}{c}\text { Nectar } \\
\text { robbers }\end{array}$ \\
\hline T. spinipes & 0.81 & $<0.001$ & Exposed & Yes \\
T. hyalinata & 0.5 & 0.014 & Exposed & Yes \\
N. subnuda & 0.46 & 0.004 & Ground & No \\
T. angustula & 0.45 & 0.029 & Caveties & No \\
\hline
\end{tabular}


Table S6. Main sampling characteristics and species composition results of studies that have measured bee diversity during the coffee blooming period, within a variety of shade management (From shaded polyculture to sun coffee production).

\begin{tabular}{|c|c|c|c|c|}
\hline Country & Sampling methodology & Sampling effort & Bee richness $\rightarrow N^{\circ}$ Bees & References \\
\hline Brazil & $\begin{array}{l}\text { Entomologial nets } \\
2 \text { min sweep-netting - twice }\end{array}$ & $\begin{array}{l}\text { 1h } \mathbf{3 6} \text { min } \\
24 \text { sites }\end{array}$ & $\begin{array}{l}20 \text { species }->169 \text { bees } \\
\text { Figure } S 6\end{array}$ & Our Study \\
\hline Brazil & $\begin{array}{l}\text { Flower observations } \\
9 \text { sessions of } 10 \mathrm{~min} \\
\text { observations per plant }\end{array}$ & $\begin{array}{c}6 \text { hours } \\
4 \text { coffee bush/plants }\end{array}$ & $\begin{array}{l}5 \text { species } \\
\text { A.mellifera }(89 \%)\end{array}$ & $\begin{array}{l}\text { Malerbo-Souza et al. } \\
2003\end{array}$ \\
\hline $\begin{array}{l}\text { Brazil - } \\
\text { vicosa }\end{array}$ & Observations? & NA & $\begin{array}{l}8 \text { species } \\
\text { A. mellifera. Dialictus*, M.quadrisfaciata*, } \\
\text { T. angustula*, T. spinipes* \& Xylocopa }\end{array}$ & $\begin{array}{l}\text { De Marco and Coelho } \\
2004\end{array}$ \\
\hline Ecuador & $\begin{array}{l}\text { Flower observations } \\
4 \text { sessions of } 15 \mathrm{~min}\end{array}$ & $\begin{array}{l}\mathbf{2 1} \text { hours } \\
21 \text { agroforest }\end{array}$ & $\begin{array}{l}29 \text { morphosps. -> } 2733 \text { bees } \\
\text { Apis mellifera }(42 \%)\end{array}$ & Veddeler et al. 2006 \\
\hline Colombia & $\begin{array}{l}\text { Flower observations } \\
10 \text { min session (shurb) }\end{array}$ & $\begin{array}{c}18 \mathrm{~h} 40 \mathrm{~min} \\
12 \text { farms }->112 \text { plants }\end{array}$ & $\begin{array}{l}\text { A. Mellifera }(59 \%) \text {; Stingless bees } \\
(40 \%)\end{array}$ & $\begin{array}{l}\text { Bravo-Monroy et al. } \\
2015\end{array}$ \\
\hline Panamá & $\begin{array}{l}\text { Flowers observations } \\
\text { Max } 3 \text { min per day - } 4 \text { days }\end{array}$ & $\begin{array}{l}\text { 1h } 28 \mathrm{~min} \\
11 \text { transects. }\end{array}$ & $\begin{array}{l}22 \text { species }->1926 \text { bees } \\
\text { Apis mellifera }(73 \%)\end{array}$ & Roubik 2002 \\
\hline Costa Rica & $\begin{array}{l}\text { Flowers observations } \\
\text { Two sessions of } 10 \mathrm{~min}\end{array}$ & $\begin{array}{l}\text { 9h 20min } \\
12 \text { sites(2001)-16 sites(2002) }\end{array}$ & 40 morphosp. -> 1041 bees & Ricketts 2004 \\
\hline Costa Rica & $\begin{array}{l}\text { Malasia Trap } \\
20 \text { coffee flushes (blooms) } \\
3 \text { days/flush }\end{array}$ & $\begin{array}{c}1,440 \text { hours } \\
9 \text { sites in } 3 X(\text { shade/sun/follow) }\end{array}$ & $\begin{array}{l}113 \text { morphosp-. -> } 1012 \text { bees } \\
\text { (34 genera) } \\
\text { Dialictus }(49 \%) \text {, Trigona }(11.5 \%)\end{array}$ & Ngo et al. 2013 \\
\hline Mexico & $\begin{array}{l}\text { Pan traps } \\
6 \text { sessions of } 8 \text { hours } \\
\text { once every two weeks ( } 6 \\
\text { before and after the coffee } \\
\text { bloom). }\end{array}$ & $\begin{array}{l}\text { 10,080 (bowls hours) } \\
30 \text { bowls (of } 6 \mathrm{oz}=177 \mathrm{ml} \text { ) } \\
\text { TOTAL: } 336 \text { hours (per site) }\end{array}$ & $\begin{array}{l}46 \text { species -> } 648 \text { bees } \\
72.2 \% \text { Halictidae and } \\
\text { Apidae } 27.8 \%\end{array}$ & $\begin{array}{l}\text { Jha \& Vandermeer } \\
2010\end{array}$ \\
\hline Brazil & $\begin{array}{l}\text { Pan Traps } \\
3 \text { bowls }(110 \mathrm{ml}) \text { per site. } \\
\text { During } 48 \mathrm{~h}\end{array}$ & $\begin{array}{c}\mathbf{3 , 4 5 6} \text { (bowl hours) } \\
\text { (1728h of day) } \\
24 \text { sites }\end{array}$ & $\begin{array}{l}16 \text { species }->67 \text { bees } \\
\text { Figure } 66\end{array}$ & Our Study \\
\hline México & $\begin{array}{l}\text { Flower observation } \\
4 \text { sessions (shrub) of } 25 \mathrm{~min}\end{array}$ & $\begin{array}{c}\text { 26h } 40 \mathrm{~min} \\
4 \text { farms } \rightarrow 4 \text { sites per farm }\end{array}$ & $\begin{array}{l}7 \text { species } \rightarrow 550 \text { bees } \\
\text { A. mellifera }(87 \%) \text {; Scaptotrigona }(7 \%)\end{array}$ & Vergara et al. 2008 \\
\hline México & $\begin{array}{l}\text { Flowers observtions } \\
10 \text { minutes sessions per plant }\end{array}$ & $\begin{array}{l}5 \text { hours } \\
30 \text { plants }\end{array}$ & $\begin{array}{l}5 \text { species -> } 55 \text { bees } \\
\text { Trigona ( } 47 \%) \text {; A. mellifera (12.7\%) }\end{array}$ & Philpott et al. 2006 \\
\hline Mexico & $\begin{array}{l}\text { Flower observations } \\
15 \text { min sessions }\end{array}$ & $\begin{array}{l}\mathbf{3 1} \text { hours } \\
124 \text { sessions }\end{array}$ & 17 species $>499$ bees & $\begin{array}{l}\text { Jha \& Vandemeer } \\
2009\end{array}$ \\
\hline India & $\begin{array}{l}\text { Flower observation } \\
15 \text { min sessions -> looking at } \\
5 \text { brances }\end{array}$ & $\begin{array}{l}176 \mathrm{~h} 15 \mathrm{~min} \\
149 \text { sites }->5 \text { bushes/site } \\
\text { TOTAL: } 10575 \mathrm{~min}\end{array}$ & $\begin{array}{l}15 \text { species }->5658 \text { bees } \\
\text { A. mellifera }(81.4 \%) \text {; Tetragonula }(18 \%)\end{array}$ & Krishnan et al. 2012 \\
\hline Indonesia & $\begin{array}{l}\text { Flower observations } \\
15 \text { min sessions on } 7 \text { coffee } \\
\text { bush per system }\end{array}$ & $\begin{array}{l}\mathbf{7} \text { h } \mathbf{3 0} \text { min } \\
10 \text { coffee systems } \\
\text { TOTAL: } 450 \mathrm{~min}\end{array}$ & $\begin{array}{l}\mathbf{2 2} \text { sps } \rightarrow \mathbf{5 1 0} \text { bees } \\
7 \text { sp socias }->312 \text { ind } \\
15 \text { sp solitary }->198 \text { ind }\end{array}$ & Klein 2002 \\
\hline Indonesia & $\begin{array}{l}\text { Flower observations } \\
3 \text { sessions (days) of } 25 \mathrm{~min}\end{array}$ & $\begin{array}{l}15 \text { sites ( } 18 \text { h } \mathbf{4 5} \text { min) } \\
24 \text { sites ( } 30 \text { hours) }\end{array}$ & $\begin{array}{l}33 \text { sp -> } 2269 \text { bees (C.canephora) } \\
29 \text { sp. -> } 2038 \text { bees (C.arabica) }\end{array}$ & Klein el al. 2003 \\
\hline
\end{tabular}

